WARSZTATY Z GEOGRAFII TURYZMU

ISBN 978-83-7525-713-7 s. 123-134

http://dx.doi.org/10.18778/7525-713-7.08

Sławomir KULA

Wyższa Szkoła Społeczno-Przyrodnicza im. Wincentego Pola

\title{
PERCEPCJA I WYKORZYSTANIE WALORÓW TURYSTYCZNYCH WOJEWÓDZTWA LUBELSKIEGO PRZEZ PRZEDSTAWICIELI LUBELSKIEGO SEKTORA ORGANIZATORÓW TURYSTYKI
}

\section{Wprowadzenie}

Walory turystyczne stanowią specyficzne cechy i elementy środowiska naturalnego oraz przejawy działalności człowieka, które są przedmiotem zainteresowania turystów (LIJEWSKI, MIKUŁOWSKI, WYRZYKOWSKI 2008). Walory można traktować również szerzej, jako zasoby turystyczne, czyli występujące obiektywne atrybuty środowiska przyrodniczego i społecznego (walory potencjalne), które dopiero po dokonaniu przez turystę odpowiedniej oceny (w wyniku zachodzenia procesu percepcji) mogą stać się faktycznymi walorami. Oznacza to, że niektóre zasoby nie muszą być dla wszystkich turystów walorami. Tym samym pojęcie „zasoby turystyczne” należy traktować jako dotyczące zjawisk obiektywnie istniejących, podczas gdy "walory turystyczne" są kategorią subiektywną (KOWALCZYK 2001).

Występowanie na danym obszarze walorów turystycznych warunkuje rozwój ruchu turystycznego. Walory stanowią podstawową siłę przyciagającą turystów i podstawowy element struktury podaży turystycznej (GOŁEMBSKI, red. 2006). 
Województwo lubelskie należy do obszarów o dużym potencjale turystycznym. W ostatnich latach podejmowano próby oceny atrakcyjności turystycznej jednostek przestrzennych różnej rangi w regionie lubelskim m.in. Lublina (ŚWIECA 2009, ŚWIECA, BRZEZIŃSKA-WÓJCIK 2009, KOCIUBA, KOCIUBA 2009, ŚWIECA, BRZEZIŃSKA-WÓJCIK 2011), wybranych jednostek administracyjnych (ŚWIECA, BRZEZIŃSKA-WÓJCIK 2009, BRZEZIŃSKA-WÓJCIK, ŚWIECA, OSMOLSKA 2006), wybranych jednostek fizycznogeograficznych (ŚWIECA, TUCKI 2007, KRUKOWSKA, ŚWIECA 2008, KRUKOWSKA, KRUKOWSKI 2009, BRZEZIŃSKA-WÓJCIK, ŚWIECA 2010), a nawet całego regionu lubelskiego (TUCKI 2007, 2009).

Mimo że region charakteryzuje się atrakcyjnymi warunkami dla rozwoju turystyki, możliwości te nie są jednak do tej pory w większym stopniu wykorzystane (KRUCZEK 2005, Koncepcja programowo-przestrzenna... 2008). Okazuje się, że posiadanie dość dużego potencjału turystycznego nie wystarczy, aby wpływy z turystyki przyniosły oczekiwane korzyści. Jednym z powodów jest słabe rozpoznanie wymagań turystów, stereotypowe podejście do promocji oraz tworzenie produktu, który nie jest oczekiwany przez turystów (TURKIEWICZ 2003).

W celu potwierdzenia między innymi tej opinii, w październiku $2009 \mathrm{r}$. zostały podjęte badania dotyczące wpływu percepcji walorów turystycznych na rozwój produktu turystycznego na przykładzie województwa lubelskiego. Dotychczas analizą objęto (odwiedzających i nieodwiedzających region lubelski) pracowników branży turystycznej, a także osoby niezwiązane z branżą turystyczną spoza województwa (KULA 2010a, b).

$\mathrm{W}$ niniejszej pracy przedstawiono wyniki badań przeprowadzonych wśród przedstawicieli lubelskiego sektora organizatorów turystyki.

\section{Charakterystyka badań}

W badaniach przeprowadzonych w pierwszej połowie $2011 \mathrm{r}$. uczestniczyła grupa 102 osób reprezentujących lubelski sektor organizatorów turystyki, pośredników turystycznych i agentów turystycznych. Badania objęły wyłącznie właścicieli $(36,1 \%)$, kierowników $(35,0 \%)$, współwłaścicieli $(17,5 \%)$ i dyrektorów $(11,4 \%)$ lubelskich przedsiębiorstw turystycznych. Zasadniczym celem badań było uzyskanie informacji z zakresu postrzegania, wykorzystania, znajomości i atrakcyjności walorów turystycznych województwa lubelskiego przez badaną populację, traktując ją jako grupę osób mających 
lub mogących mieć w przyszłości wpływ na tworzenie i sprzedaż lubelskich produktów turystycznych.

W procedurze badawczej zastosowano bezpośredni wywiad ankietowy, przeprowadzony w siedzibach 82 przedsiębiorstw (tab. 1). W regionie lubelskim największa ich koncentracja $(59,8 \%)$ występuje na terenie Lublina.

Tabela 1. Przedsiębiorstwa turystyczne według miejsca i przedmiotu prowadzonej działalności

\begin{tabular}{|c|c|c|c|c|c|c|c|c|}
\hline \multirow{3}{*}{ Miasto } & \multirow{3}{*}{$\begin{array}{c}\text { Procentowy } \\
\text { udział } \\
\text { w próbie }\end{array}$} & \multirow{3}{*}{$\begin{array}{c}\text { Liczba } \\
\text { punktów } \\
\text { badania }\end{array}$} & \multicolumn{6}{|c|}{ W tym } \\
\hline & & & \multirow{2}{*}{$\begin{array}{c}\mathrm{OT} / \mathrm{PT} \\
\text { /AT }\end{array}$} & \multirow{2}{*}{ OT / AT } & \multirow{2}{*}{ OT } & \multirow{2}{*}{$\mathrm{PT} / \mathrm{AT}$} & \multirow{2}{*}{ PT } & \multirow{2}{*}{ AT } \\
\hline & & & & & & & & \\
\hline Biała Podlaska & 4,8 & 4 & 2 & & 2 & & & \\
\hline Biłgoraj & 3,6 & 3 & & 1 & 1 & & & 1 \\
\hline Chełm & 6,1 & 5 & 2 & & & 1 & & 2 \\
\hline Krasnystaw & 1,2 & 1 & & & & 1 & & \\
\hline Kraśnik & 1,2 & 1 & 1 & & & & & \\
\hline Lubartów & 1,2 & 1 & & & & & & 1 \\
\hline Lublin & 59,8 & 49 & 19 & 2 & 10 & 3 & 3 & 12 \\
\hline Łęczna & 4,8 & 4 & 2 & & & & 1 & 1 \\
\hline Puławy & 4,1 & 3 & 1 & & & & & 2 \\
\hline Radzyń Podlaski & 2,4 & 2 & & & 1 & & & 1 \\
\hline Świdnik & 1,2 & 1 & 1 & & & & & \\
\hline Tomaszów Lub. & 2,4 & 2 & 1 & 1 & & & & \\
\hline Zamość & 7,2 & 6 & 5 & 1 & & & & \\
\hline Razem & 100,0 & 82 & 34 & 5 & 14 & 5 & 4 & 20 \\
\hline
\end{tabular}

Objaśnienia: OT - organizatorzy turystyki, PT - pośrednicy turystyczni, AT - agenci turystyczni. Źródło: badania własne.

Analiza krajowych ofert turystycznych w 82 podmiotach wykazała, że $55 \mathrm{z}$ nich posiada w swojej ofercie imprezy turystyczne realizowane na terenie województwa lubelskiego. Oferta ta stanowiła największy odsetek wśród krajowych imprez turystycznych, kolejne miejsca zajmują województwo małopolskie oraz województwa ościenne: podkarpackie, świętokrzyskie i mazowieckie (rys. 1). Spośród wszystkich analizowanych podmiotów 10 ma w swojej ofercie wyłącznie imprezy zagraniczne. 


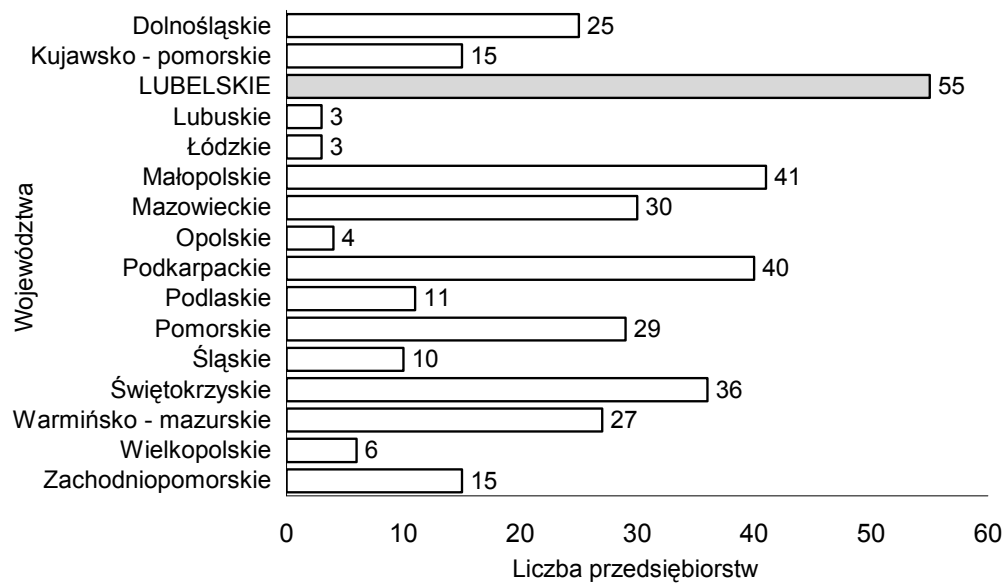

Rys. 1. Dostępne kierunki wyjazdów w ofercie krajowej w badanych przedsiębiorstwach turystycznych

Źródło: badania własne

Liczba respondentów pod względem struktury płci była zrównoważona: kobiet było 48,5\%, a mężczyzn 51,5\%. Struktura wieku respondentów przedstawiała się następująco: osoby w wieku 25-29 lat stanowiły 26,8\%, 30-39 lat $-36,1 \%$, 40-49 lat $-17,5 \%$, 50-59 lat $-14,4 \%$, powyżej 59 lat $-5,2 \%$.

\section{Wyniki badań}

Tylko około 10\% osób reprezentujących lubelski sektor organizatorów turystyki odpowiedziało, że nie podróżuje po Lubelszczyźnie w celach turystycznych. Byli to wyłącznie właściciele i współwłaściciele przedsiębiorstw, którzy uzasadniali odpowiedź tym, że albo już poznali ten region w przeszłości i wyjeżdżają w inne zakątki kraju i świata, albo tłumaczyli „brakiem czasu” na taką podróż.

Zdecydowana większość badanej populacji (90,7\%) korzystała z przestrzeni turystycznej regionu, z czego prawie $80 \%$ podejmowała taką podróż częściej niż raz w roku, najczęściej 6-10 razy $(25,4 \%)$ i 4-5 razy w roku $(24,1 \%)$, rzadziej - 2-3 razy w roku, podróżowało po Lubelszczyźnie 19,5\%, a raz w roku - 17,2\%. Najrzadziej była wskazywana podróż częściej niż 10 razy $w$ roku $(9,2 \%)$ i raz na kilka lat $(4,6 \%)$. 
Głównymi celami podróży wskazywanymi przez respondentów był wypoczynek, zapoznanie $\mathrm{z}$ regionem i turystyka aktywna. Cele te często były współzależne ze sobą. Pozostałe cele stanowiły mniejszy odsetek wskazań (rys. 2).

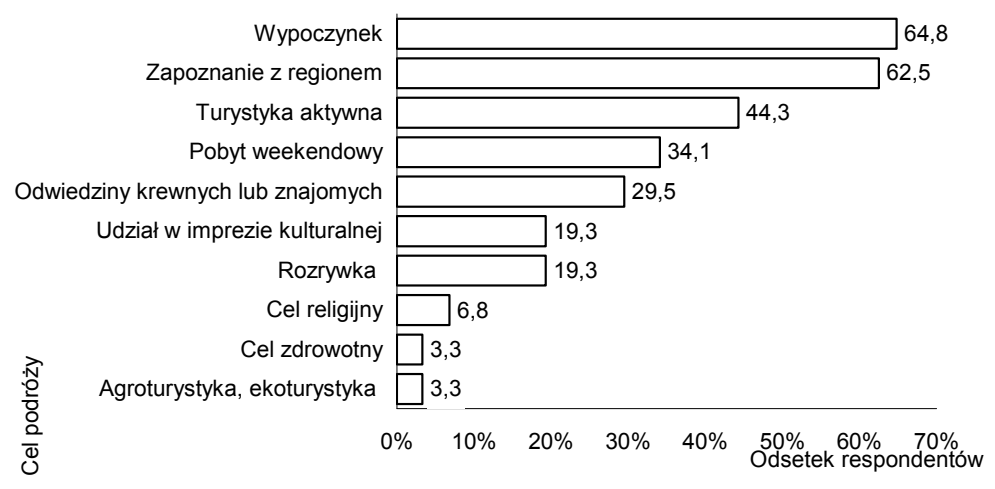

Rys. 2. Główne cele podróży respondentów po Lubelszczyźnie (możliwość wyboru trzech odpowiedzi) Źródło: badania własne

Podczas podróży po Lubelszczyźnie ponad 17\% badanych nie korzystało z noclegu. Pozostali (ok. 83\%) nocowali, najczęściej (ponad 50\% wskazań) w obiektach zbiorowego zakwaterowania, tj. w hotelach i ośrodkach wypoczynkowych (po 16,1\% dla każdego obiektu), pensjonatach $(12,2 \%)$ oraz w schroniskach młodzieżowych i na kempingach (po 3\% dla każdego obiektu). Z bazy nierejestrowanej (mieszkania znajomych/rodziny) skorzystało $14,5 \%$ ankietowanych, z kwater prywatnych $11,4 \%$, a z gospodarstw agroturystycznych jedynie $6,1 \%$.

Najczęściej wykorzystywanym środkiem transportu podczas podróży był samochód osobowy (80,7\%). Znacznie rzadziej autokar wycieczkowy $(9,8 \%)$, rower $(5,9 \%)$, pociang $(1,8 \%)$ oraz autobus kursowy i motocykl (po $0,9 \%$ wskazań każdy).

W czasie podróży respondentom przeważnie towarzyszyła rodzina (57,9\%), najczęściej współtowarzyszyły im dwie lub trzy osoby, najczęściej dzieci do lat $14(54,8 \%)$, głównie jedno lub dwoje. Stosunkowo duży udział miały wskazania podróży z grupą przyjaciół/znajomych $(31,8 \%)$, głównie trzy lub cztery osoby. Niewiele ponad $10 \%$ podróżowało z grupą zorganizowaną (najczęściej 20- lub 50-osobową). Nie wskazano na podróż w pojedynkę. 
Najczęściej odwiedzanymi przez respondentów miejscowościami na Lubelszczyźnie były: Kazimierz Dolny (53,4\%), Nałęczów (20,5\%), Zamość $(15,9 \%)$ oraz Kozłówka (10,3\%). Wybieranie tych miejsc jako celu podróży wśród badanej populacji wynika zarówno z wysokich walorów turystycznych tych miejscowości, mody na nie (w szczególności na Kazimierz Dolny i Nałęczów), jak i z dobrej dostępności komunikacyjnej z Lublina, skąd pochodzi większość respondentów. Pozostałe miejscowości były znacznie rzadziej wymieniane.

Zestawienie wskazywanych przez respondentów miejsc jako najczęściej odwiedzanych ukazuje znaczne zróżnicowanie przestrzenne atrakcyjności turystycznej Lubelszczyzny. Wyniki analiz wskazuja, że najbardziej popularnym miejscem wypoczynku dla przedstawicieli lubelskiego sektora organizatorów turystyki (94,3\% wskazań) jest obszar objęty działalnością Lokalnej Organizacji Turystycznej „Zamość i Roztocze”. W tej części Lubelszczyzny najczęściej wybierany był obszar Roztocza (49,4\%) oraz miejscowości: Zamość (16,9\%), Zwierzyniec (12,1\%), Krasnobród i Susiec (po 9,6\%) oraz Horyniec Zdrój i Narol (po 1,2\%).

Obszar objęty zasięgiem Lokalnej Organizacji Turystycznej „Kraina Lessowych Wąwozów" uzyskał 87,5\% wskazań. W tym przypadku zdecydowanie najczęściej wymieniany był Kazimierz Dolny $(63,6)$ i Nałęczów $(26,0 \%)$, znacznie rzadziej Janowiec (6,5\%) i Puławy (3,9\%).

Na miejsca objęte działalnością Stowarzyszenia Poleskiej Lokalnej Organizacji Turystycznej przypadło natomiast 53,4\% wskazań. Najczęściej wymieniano obszar Pojezierza Łęczyńsko-Włodawskiego i Polesia Lubelskiego (63,9\%). Spośród miejscowości tego obszaru najczęściej (17,1\% wskazań) wymieniano Okuninkę nad J. Białym, na pozostałe miejscowości położone na tym obszarze przypadło 19,0\% wskazań.

Na pozostałe najczęściej odwiedzane miejsca przypadło 35,2\% wskazań. W tej grupie na uwagę zasługuje Kozłówka (30,0\% odpowiedzi), Janów Lubelski i Lublin (po 19,3\%), Firlej (9,6\%), Janów Podlaski (3,2\%) oraz inne miejsca (w sumie 9,0\%). Pobyty miały w większości charakter krótkoterminowy (do trzech dni), głównie w sezonie turystycznym (rys. 3 i 4).

Istotnym zagadnieniem $\mathrm{w}$ badaniu było uzyskanie informacji na temat skojarzeń z Lubelszczyzną. Respondenci najczęściej wskazywali: obszar $67,6 \%$ (w tym Roztocze - 30,5\%, Lublin - 28,9\%, Polesie Lubelskie i Pojezierze Łęczyńsko-Włodawskie - 13,1\%, Zamość - 11,6\%, Kazimierz Dolny 8,7\%, Nałęczów - 5,8\% i Kozłówka - 1,4\%), walory przyrodnicze - 56,8\% (w tym przyroda nieskażona - 67,3\% i nieprzekształcona przez człowieka $32,7 \%$ ), krajobraz - 20,6\% („malownicze”, wyżynne ukształtowanie terenu $42,9 \%$, krajobraz rolniczy - 38,1\% i lessowe wąwozy - 19,0\%), gospodarkę - 


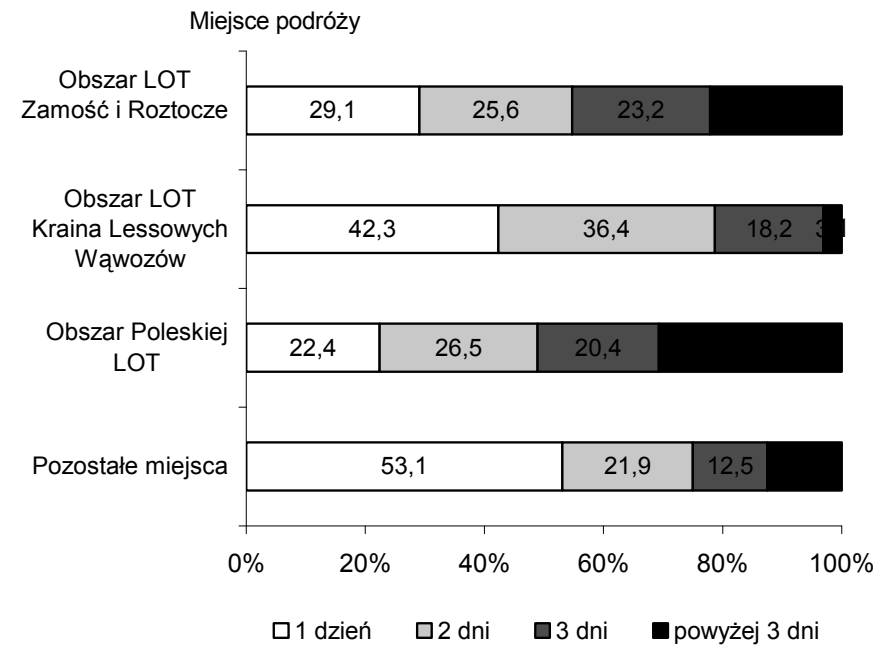

Rys. 3. Długość trwania podróży po Lubelszczyźnie w miejscach wskazanych przez respondentów

Źródło: badania własne

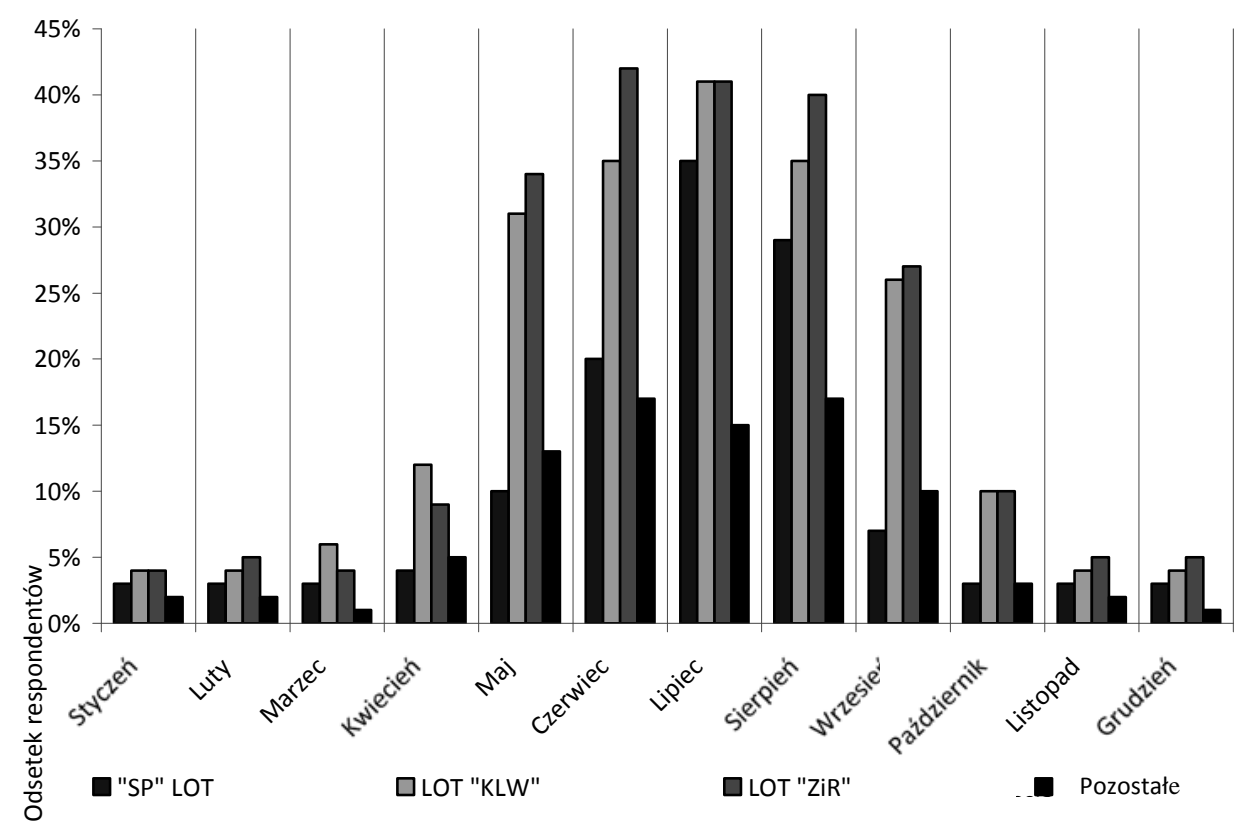

Rys. 4. Termin pobytu w miejscach wskazanych przez respondentów Źródło: badania własne 
12,7\%, (zacofanie gospodarcze regionu - 76,9\% i bezrobocie - 23,1\%). W grupie pozostałych skojarzeń, która obejmowała 35,3\% wskazań, znalazły się m.in.: zły stan infrastruktury drogowej, Perła - Browary Lubelskie, wielokulturowość regionu, Koziołek Lubelski, turystyka aktywna, renesans lubelski, budowle sakralne, Unia Lubelska, makaron i gościnność.

Według 92,7\% badanej populacji województwo lubelskie jest atrakcyjne turystycznie: „zdecydowanie tak" dla 44,8\% respondentów, „raczej tak” dla $47,9 \%$.

Ponad połowa ankietowanych twierdzi, że województwo lubelskie wyróżnia się na tle pozostałych województw w Polsce, z czego „zdecydowanie tak" w 13,4\% i „raczej tak” w 46,4\% przypadków. Pozytywne elementy wyróżniające województwo, to m.in.: walory naturalne - 33,7\% (dziewicza przyroda, odmienny krajobraz, liczne jeziora), wielokulturowość - 20,5\% (odmienna i bogata kultura regionu, żywa kultura ludowa, pozostałości po kulturze żydowskiej, wschodnia gościnność, granica z Ukrainą i Białorusią), zabytki architektury - 18,1\% (unikatowe w skali kraju obiekty w Kazimierzu Dolnym i w Nałęczowie, renesans lubelski, zabytki z listy UNESCO), ekologia - 16,8\% (obszar ekologicznie czysty, nieprzekształcony przez człowie$\mathrm{ka}$, region rolniczy pozbawiony przemysłu), odmienne krajobrazy $-7,2 \%$ i bogata historia regionu $-3,7 \%$.

Według pozostałych badanych województwo lubelskie nie wyróżnia się na tle innych województw Polski („raczej nie” - 37,1\% wskazań i „zdecydowanie nie" $-3,1 \%$ ). Wśród udzielonych odpowiedzi wymieniano fakt, że inne województwa mają więcej możliwości spędzenia czasu podczas pobytu na ich obszarze oraz bardziej rozpoznawalne atrakcje turystyczne $(35,1 \%$ odpowiedzi), dysponują bardziej rozbudowaną infrastrukturą turystyczną $(32,4 \%)$, prowadzą intensywniejszą kampanię promocyjną $(21,6 \%)$ oraz są bardziej popularne wśród turystów, co uzasadniają faktem, że województwo lubelskie położone jest na tzw. „ścianie wschodniej Polski”, która według respondentów nie jest popularnym kierunkiem wyjazdów turystycznych $(10,9 \%)$.

W zakresie największych atrakcji turystycznych respondenci wskazali 766 lubelskich produktów turystycznych. Są to produkty z grupy "obszar" (54,5\%), "obiekt” (22,2\%), „wydarzenie" (12,3\%), „szlak” (4,1\%), „impreza” $(3,9 \%)$, „usługa" $(1,8 \%)$ i „,rzecz” (1,2\%). Ankietowani najczęściej wymieniali produkty: Kazimierz Dolny (82,3\%), Zamość (73,5\%), Zamek Lubelski (54,9\%), Zespół Pałacowo-Parkowy w Kozłówce $(47,1 \%)$, Roztocze $(45,1 \%)$, Polesie Lubelskie/Pojezierze Łęczyńsko-Włodawskie (29,4\%), Kraina Lessowych Wąwozów/„Trójkąt turystyczny”: Puławy-Kazimierz Dolny-Nałęczów i Lublin (po 24,5\% wskazań na każdy produkt), Festiwal Filmowy 
w Kazimierzu Dolnym i Roztoczański Park Narodowy (po 21,6\% wskazań na każdy produkt), Poleski Park Narodowy (20,6\%), Podziemia kredowe w Chełmie (19,6\%), Szlak szumów w Puszczy Solskiej, Jarmark Jagielloński w Lublinie, Starówka w Lublinie (po 18,5\% wskazań na każdy produkt), Muzeum na Majdanku (13,7\%) i Zwierzyniec (11,8\%).

Po przyporządkowaniu wymienionych produktów turystycznych, wytypowanych przez respondentów jako najbardziej atrakcyjne w regionie, do konkretnej przestrzeni turystycznej Lubelszczyzny, uzyskane wyniki badań wskazały, że największa ich koncentracja występuje na obszarach objętych działalnością Lokalnych Organizacji Turystycznych "Zamość i Roztocze" $(30,2 \%)$ i „Kraina Lessowych Wąwozów (26,2\%). Prawie 20\% przypadło na miasto lub walory turystyczne Lublina, a niespełna $9 \%$ na obszar działalności Stowarzyszenia Poleskiej Lokalnej Organizacji Turystycznej. Na pozostałe miejsca lub atrakcje turystyczne przypadło prawie $16 \%$ (tab. 2).

Tabela 2. Najważniejsze atrakcje turystyczne Lubelszczyzny wskazane przez respondentów

\begin{tabular}{|c|c|c|}
\hline $\begin{array}{l}\text { Obszar występowania } \\
\text { produktu turystycznego }\end{array}$ & Produkt turystyczny & $\begin{array}{c}\text { Udział } \\
\%\end{array}$ \\
\hline$[1]$ & [2] & [3] \\
\hline \multirow{13}{*}{$\begin{array}{l}\text { Obszar objęty działalnością } \\
\text { LOT „Zamość i Roztocze" } \\
(\mathbf{3 0 , 2 \% )}\end{array}$} & Zamość & 32,3 \\
\hline & Roztocze & 19,8 \\
\hline & Roztoczański Park Narodowy & 9,5 \\
\hline & Szlak szumów w Puszczy Solskiej & 8,2 \\
\hline & Zwierzyniec & 5,2 \\
\hline & Letnia Akademia Filmowa w Zwierzyńcu & 3,8 \\
\hline & Rajdy rowerowe po Roztoczu & 3,8 \\
\hline & Spływy kajakowe po Roztoczu & 3,2 \\
\hline & Krasnobród & 3,1 \\
\hline & Inscenizacja Bitew pod Tomaszowem Lubelskim & 1,9 \\
\hline & Jarmark Hetmański w Zamościu & 1,9 \\
\hline & Siedliska & 1,4 \\
\hline & Inne & 5,9 \\
\hline & & 100,0 \\
\hline \multirow{10}{*}{$\begin{array}{l}\text { Obszar objęty działalnością } \\
\text { LOT „Kraina Lessowych } \\
\text { Wąwozów" } \\
(\mathbf{2 6 , 2 \% )}\end{array}$} & Kazimierz Dolny & 41,8 \\
\hline & Nałęczów & 14,9 \\
\hline & "Tróikąt turystyczny" / Kraina Lessowych Wąwozów & 12,4 \\
\hline & Festiwal Filmowy w Kazimierzy Dolnym & 10,9 \\
\hline & Spa \& Wellnes w Nałęczowie & 5,5 \\
\hline & Ogólnopolskie Warsztaty Kowalskie w Wojciechowie & 3,0 \\
\hline & Zamek w Janowcu & 3,0 \\
\hline & Festiwal Kapel Ludowych i Śpiewaków Ludowych w KD & 2,5 \\
\hline & Zespół Pałacowo - Parkowy w Puławach & 2,5 \\
\hline & Inne & 3,5 \\
\hline & 100,0 \\
\hline
\end{tabular}




\begin{tabular}{|c|c|c|}
\hline [1] & [2] & [3] \\
\hline \multirow{10}{*}{$\begin{array}{l}\text { Obszar miasta Lublin } \\
(\mathbf{1 9 , 3 \% )}\end{array}$} & Kaplica Trójcy Świetei na Zamku Lubelskim & 27,7 \\
\hline & Lublin & 16,9 \\
\hline & Jarmark Jagielloński & 12,9 \\
\hline & Starówka & 12,9 \\
\hline & Zamek Lubelski & 10,1 \\
\hline & Muzeum na Majdanku & 9,5 \\
\hline & Noc kultury & 4,1 \\
\hline & Szlak Pamięci Żydów Lubelskich & 1,9 \\
\hline & Zalew Zemborzycki & 1,9 \\
\hline & Inne & 2,1 \\
\hline & & 100,0 \\
\hline \multirow{5}{*}{$\begin{array}{l}\text { Obszar objęty działalnością } \\
\text { Stowarzyszenia Poleskiej LOT } \\
(\mathbf{8 , 6 \% )}\end{array}$} & Polesie Lubelskie / Pojezierze Łęczyńsko-Włodawskie & 45,4 \\
\hline & Poleski Park Narodowy & 31,8 \\
\hline & Festiwal Trzech Kultur w Włodawie & 12,1 \\
\hline & Okuninka nad Jeziorem Białym & 6,1 \\
\hline & Inne & 4,6 \\
\hline & & 100,0 \\
\hline \multirow{6}{*}{$\begin{array}{l}\text { Pozostałe } \\
(\mathbf{3 0 , 2} \%)\end{array}$} & Zespół Pałacowo-Parkowy w Kozłówce & 40,0 \\
\hline & Podziemia kredowe w Chełmie & 16,7 \\
\hline & Stadnina Koni Arabskich w Janowie Podlaskim & 4,2 \\
\hline & Chmielaki Krasnostawskie & 4,1 \\
\hline & Lasy Janowskie & 3,4 \\
\hline & Inne & 31,6 \\
\hline & 100,0 \\
\hline
\end{tabular}

Źródło: badania własne.

W badaniu uwzględniono, proponowane przez reprezentantów lubelskiego sektora organizatorów turystyki, zmiany mające na celu uatrakcyjnienie pobytu na Lubelszczyźnie. Znaczny udział uzyskały:

- poprawa zagospodarowania turystycznego regionu - 65,7\%; przede wszystkim wskazywana była tutaj baza noclegowa (62,7\%), którą należałoby rozbudować i przystosować do obsługi mniej zamożnego klienta; pozostałe uwagi dotyczyły rozbudowy i modernizacji bazy gastronomicznej, towarzyszącej oraz paraturystycznej);

- inwestycje w infrastrukturę drogową - 43,1\%; w szczególności mające na celu podwyższenie standardu i jakości nawierzchni dróg;

- polepszenie wewnętrznej i zewnętrznej dostępności komunikacyjnej regionu $-31,4 \%$;

- zwiększenie inwestycji na działania promocyjne - 23,6\%.

Wśród propozycji znalazły się także: tworzenie nowych kompleksowych produktów turystycznych $(19,5 \%)$, poprawa systemu informacji turystycznej i oznakowania atrakcji turystycznych $(17,6 \%)$, zmiany kadrowe wśród decy- 
PERCEPCJA I WYKORZYSTANIE WALORÓW TURYSTYCZNYCH WOJEWÓDZTWA LUBELSKIEGO...

dentów z zakresu turystyki na szczeblu wojewódzkim (5,9\%), większa dbałość o czystość i porządek $(4,9 \%)$ oraz zaspokajanie realnych potrzeb turystów $(1,9 \%)$.

\section{Podsumowanie}

Przedstawiciele lubelskiego sektora organizatorów turystyki często korzystają z przestrzeni turystycznej regionu w celach typowo turystycznych, najczęściej jest to aktywny wypoczynek połączony z krajoznawstwem.

Prawie $60 \%$ badanych podmiotów ma w swojej ofercie imprezy turystyczne realizowane $\mathrm{w}$ województwie lubelskim.

Najczęściej wybieranym miejscem wypoczynku dla badanej grupy są obszary Roztocza, Trójkąta turystycznego: Puławy-Kazimierz-Nałęczów i Pojezierza Łęczyńsko-Włodawskiego oraz miejscowości Kazimierz Dolny, Nałęczów, Zamość i Kozłówka. Są one zarazem uznawane jako najbardziej atrakcyjne w województwie.

Ponad 90\% respondentów uznaje, że województwo jest atrakcyjne turystycznie, ponad $50 \%$ uważa, że wyróżnia się ono pod tym względem na tle pozostałych województw Polski.

Zgłaszane propozycje uatrakcyjnienia pobytu na Lubelszczyźnie dotyczą zagadnień ogólnych i nie wnoszą niczego nowego w tym zakresie. Jedynie niecałe $2 \%$ badanych dostrzegła konieczność stosowania orientacji marketingowej w regionie, wskazując na traktowanie potrzeb turystów jako czynnika o podstawowym znaczeniu przy kreowaniu oferty turystycznej.

Zachowania turystyczne badanej populacji wskazują na bierne wykorzystywanie istniejących produktów turystycznych i małą kreatywność w poszukiwaniu nowych sposobów spędzenia czasu, co w przyszłości mogłoby wpłynąć na wzbogacenie ich oferty.

\section{BIBLIOGRAFIA}

BRZEZIŃSKA-WójCIK T., ŚWIECA A., 2010, Przyrodnicze uwarunkowania rozwoju turystyki w wybranych gminach Wyniosłości Giełczewskiej, „Problemy Ekologii Krajobrazu”, t. XXVII, Warszawa-Biała Podlaska, s. 65-72.

BRZEZIŃSKA-WÓJCIK T., ŚWIECA A., OSMOLSKA B., 2006, Obiekty sakralne jako element atrakcyjności turystycznej w gminach przygranicznych województwa lubelskiego, [w:] G. Godlewski, M. Bochenek (red.), Walory turystyczne Euroregionu Bug jako czynnik aktywności gospodarczej i inte- 
gracji społeczno-kulturalnej, Wyd. Akademii Wychowania Fizycznego w Warszawie, Zamiejscowy Wydział Wychowania Fizycznego w Białej Podlaskiej, Biała Podlaska, s. 176195.

GoŁEMBSKI G. (red.), 2006, Kompendium wiedzy o turystyce, PWN, Warszawa.

Kocuba D., Kociuba W., Potencjat turystyczny Lublina jako czynnik rozwoju miasta na przestrzeni wieków, „Annales UMCS”, sec. B, LXIV, 1, s. 213-227.

Koncepcja programowo-przestrzenna rozwoju turystyki i rekreacji w województwie lubelskim. Cele i główne kierunki rozwoju sektora turystyki i rekreacji, 2008, Zarząd Województwa Lubelskiego, Lublin, ss. 238.

KOWALCZYK A., 2001, Geografia turyzmu, PWN, Warszawa.

KRUCZEK Z., 2005, Polska, Geografia atrakcji turystycznych, Proksenia, Kraków.

KRUKOWSKA R., KRUKOWSKI M., 2009, Ocena atrakcyjności turystycznej Pojezierza Łęczyńsko-Włodawskiego, "Annales UMCS”, sec. B, LXIV, 1, s. 7-96.

KRUKOWSKA R., ŚWIECA A., 2008, Osadnictwo letniskowe jako jedna z form wykorzystania turystycznego obszarów wypoczynkowych na przykładzie Pojezierza Łęczyńsko-Włodawskiego, [w:] J. Wyrzykowski (red.), Uwarunkowania rozwoju turystyki zagranicznej w Europie Środkowej i Wschodniej, t. 10: Turystyka w środowisku geograficznym, Wyd. Instytutu Geografii i Rozwoju Regionalnego Uniwersytetu Wrocławskiego, s. 187-196.

Kula S., 2010a, Percepcja walorów turystycznych województwa lubelskiego - na przykładach osób, które odwiedzity region, Zeszyty Naukowe WSSP, 9, Wyd. Akademickie WSSP, Lublin, s. 89-104.

KULA S., 2010b, Percepcja walorów turystycznych województwa lubelskiego - na przykładach osób, które nie odwiedzity regionu, „Problemy Ekologii Krajobrazu”, t. XXVII, Warszawa-Biała Podlaska, s. 245-251.

LIJEWSKI T., MIKUŁOWSKI B., WYRZYKOWSKI J., 2008, Geografia turystyki Polski, PWE, Warszawa.

ŚwIECA A., 2009, Miasto Lublin jako przestrzeń turystyczna, [w:] J. Styk, A. Świeca (red.), Stare i nowe struktury spoteczne w Polsce, t. 8. Wyd. UMCS, Lublin, s. 69-92.

ŚWIECA A., BRZEZIŃSKA-WÓjCIK T., 2009, Zasoby turystyczne i możliwości ich wykorzystania na obszarze miasta i gminy Nałęczów oraz gminy Wojciechów, "Annales UMCS”, sec. B, LXIV, 1, s. $145-170$.

ŚWIECA A., BRZEZIŃSKA-WÓJCIK T., 2011, Zróżnicowanie przestrzeni turystycznej miasta Lublina, [w:] B. Włodarczyk (red.), Turystyka. Księga jubileuszowa w 70 rocznicę urodzin Profesora Stanisława Liszewskiego, Wyd. Uniwersytetu Łódzkiego, Łódź, s. 231-249.

ŚWIECA A., BRZEZIŃSKA-WÓJCIK T., KOCIUBA W., 2009, Charakterystyka przestrzeni przyrodniczej terytorium miasta Lublina, [w:] J. Styk, A. Świeca (red.), Stare i nowe struktury społeczne w Polsce, t. 9. Wyd. UMCS, Lublin, s. 13-34.

ŚWIECA A., TUCKI A., 2007, Uwarunkowania geograficzne i perspektywy rozwoju turystyki na przykładzie wybranego obszaru Pojezierza Łęczyńsko-Włodawskiego, [w:] J. Bergier, M. Stelmach (red.), Kierunki rozwoju turystyki w województwie lubelskim, Wyd. PWSZ w Białej Podlaskiej, Biała Podlaska, s. 91-107.

TUCKI A., 2007, Uwarunkowania funkcjonalne rozwoju gospodarki turystycznej w regionie lubelskim, [w:] J. Wyszkowski (red.), Rola turystyki w gospodarce regionu, Wyższa Szkoła Handlowa, Wrocław, s. 68-79.

TUCKI A., 2009, Potencjał turystyczny regionu lubelskiego, „Annales UMCS”, sec. B, LXIV, 1, s. 15-35.

TURKIEWICZ E., 2003, Materiaty Krakowskiej Agencji Rozwoju Turystyki „Koncepcja Szlaku Architektury Drewnianej", KART, Kraków. 